\title{
Virtuous Engineering is the Need of Hour: A Perspective for Civil Engineering Research
}

\author{
Nirbhay Kumar Mishra* \\ GLA University, India \\ Submission: March 13, 2018; Published: May 11, 2018 \\ *Corresponding author: Nirbhay Kumar Mishra, Assistant Professor (Professional Ethics), GLA University Mathura, Uttar Pradesh, India, \\ Email: nirbhay.mishra@gla.ac.in
}

\begin{abstract}
The best quality of someone or something that creates something valuable can be considered as virtuous. The present article frames the engineering ethics, what I call the virtuous engineering, from the civil engineering perspective. Civil engineering can be comprehended in the sense of imagining, innovating and creating such structures and designs which not only make social life more convenient but also civilized. The engineering skills and virtues it involves in its engineering designs and structures represent the character of the society. From the ancient Giza Pyramids to the latest Qingdao Halwan Bridge all narrates the beauty, virtues, skills, techniques, challenging will and civil engineering attitude of their societies. The article construes the ethical enhancement in the civil engineering as a mark of social developments. The article is innovative and explorative in its analysis in the fashion it involves engineering ethics, aesthetics and socio matrix in understanding the civil engineering creativity.
\end{abstract}

Keywords: Engineering ethics; Engineering creativity; Utilitarianism; Virtue theory; Deontology

\section{Introduction}

Aristotle defines about the virtues as characteristics having their purpose to achieve what they aimed to. And, when we are virtuous in terms of what we do actually we realize a state of mind filled with happiness that's what he calls Eudemonia. Engineering creations in general and civil engineering in particular have to focus on this engineering ethics as it is the need of hour to maintain a grater balance of good through engineering creativity. The mantra of any industrious act, whatever it involves whether the engineering or the business corporate proceedings, is to maintain the Triple bottom line:
1) People,
2) Planet and
3) Profit.

Following the same line of thinking the paper has a vision of civil engineering in which it defends that the civil engineering is not only an act of engineering but also it represent the social character. Hence, the great civil engineering designs, structures, and achievements all they act as representative benchmarks for the society and to the idea of social development. The emphasis has been put more on the ethical side of civil engineering in a manner it really involves the ethical ideas to make social life civic by providing such civil engineering creations that give to society a morally better and healthy life; let's talk about the very basic concept of room having doors and windows what these structures facilitates in terms of making a better moral life that is having privacy with the choice of exposure. In this explorative effort I shall be concluding with the remarks that the future of civil engineering is of Green ethical engineering which encapsulates the virtuous creativity, Happy Society and Environmental Safety.

\section{Civil Engineering as Virtuous Engineering: Understanding from Giza to Qingdao Halwan Bridge}

From the ancient time creativity has been shaped by the human mind through natural beauty and its underlying aesthetic philosophy. However, there is a gradual fall down in this kind of engineering thinking. And it has alarmed us to restructure the engineering view before we imagine creating any technology, machine, design or structures. The need of hour is the virtuous engineering modal which not only encompassing the basic engineering skills but also the engineering ethics that it should be in order to facilitate a society in making the social life more convenient, civilized, and healthy. Let's talk about the Giza Pyramid; the oldest civil engineering wonder of the world. Alexander writes:

In the ancient world there once stood seven wonders, seven monuments of the ingenuity of men. The civilizations fell, and those wonders crumbled to dust, lost in the sands of time all 
except one: The Great Pyramid of Giza. It is spawned countless myths, but its real story is about triumph over impossible odds, extraordinary human ingenuity and one man's burning ambition to live forever. It is 4.500 years old, the only ancient wonder of the world still standing and it is the oldest [1].

How specialized civil engineering skills being personified in the creation in terms of aesthetics, skills and engineering design. The famous Arabic proverb philosophically states:

Man fears the time, but the time fears pyramids [1].

The purpose of the pyramids was religious however it exemplified the world-class civil engineering design. The oldest civilized burial system with structural protection and enhanced social respect and security shows the ethical engineering philosophy inbuilt in the built structures.

Let's talk about the most recently civil engineering structure of the current time: Qingdao Halwan Bridge built by China. The world's longest cross Sea Bridge recorded in the Guianese Book. Purposefully connecting the eastern and western of the Qingdao regions in China represents the industriousness and top civil engineering creation. And, this gigantic creation will be an international shipping center of North-East Asia. However, this and the other recent civil engineering creations are missing what is the purpose of this explorative paper and that is engineering without ethical virtues [2].

This is the very difference that has been glared in the recent past civil engineering will to create world class designs and structures that earlier in the ancient times the engineering creations were holistic in the way they value not only technology , innovation and creation but also the ethics, environment and earth; protecting nature from the damage. The socio-economic development of Qingdao city and the civil engineering creation around have put the coastal and marine at stake [3-5].

The very ancient Indus Valley Civilization is honorific example of value based civil engineering. In this we find the houses, roads, sanitation mechanism, and big structures for collective celebrations such as Great Bath at Mohenjodaro. The engineering will and the social character it reflects in the structures and design tells all the story that the civil engineering of that time was ethically equipped with good social development. The centralized governance system was found in the civilization and well functioning as the measurement units were almost same in all the engineering creations.

We have to understand the above as social developments through civil engineering creations. All the above examples from ancient to the Modern civil engineering is to make the contrast in terms of the understanding that the time has come to realize that the ancient holistic civil engineering philosophy based on the protection of nature and society is the way out to the existing social-environmental problems. Hence, we need to be virtuous in our civil engineering imagination. Before we create anything or think about any technological advancement in the stream. We should focus one of the purposes of civil engineering: Creating better societies and reflecting it in their structures and designs in the fashion that they actually revels the ethical character of the society in their engineering mask and make ups as expressed in the figure below [6].

\section{Ethical Point of Views for Civil Engineering Creativity: Virtue Theory, Utilitarianism and Deontology}

Virtue theory was developed by Aristotle and he argues from the Arete that is the moral excellence. It is the highest virtue. Aristotelian virtue theory gives directions to civil engineering for this time is to incorporating the genuine imagination, aesthetics, innovation in civil engineering without the thinking of the use and profits. According to him every human endeavor has a purpose to express the virtues and qualities by which it should be performed and further the expressed virtues have a purpose and it is to create a better society. So, civil engineering creativity has a larger purpose and that is to create a better society and better world to live in [7].

Jeremy Bentham in his view of Utilitarianism says that we should act on the principle of utility in maximizing goodness for maximum number of people. Later on the theory was strengthened by his disciple John Stuart Mill who added the qualitative aspects in terms of making higher order choice in choosing what is of utility. Taking the ethical point of view the recent civil engineering philosophy should buy the reasons given by Mill in his Utilitarianism that the creativity should be such that it should not only be maximizing the social utility and happiness but also respecting social health and natural environment as qualitatively better choice [8-10].

Extracting the ethical points from the Deontology we can recommend for the civil engineering that the virtue and the utility are not the two crucial factors only for the engineering imagination and engineering will but the imagination should be responsible in terms, that it take care of the duties which are adhered to the engineering profession. Such duties involves duties to be truthful to profession, integrity and careful to humankind and society Figure1.

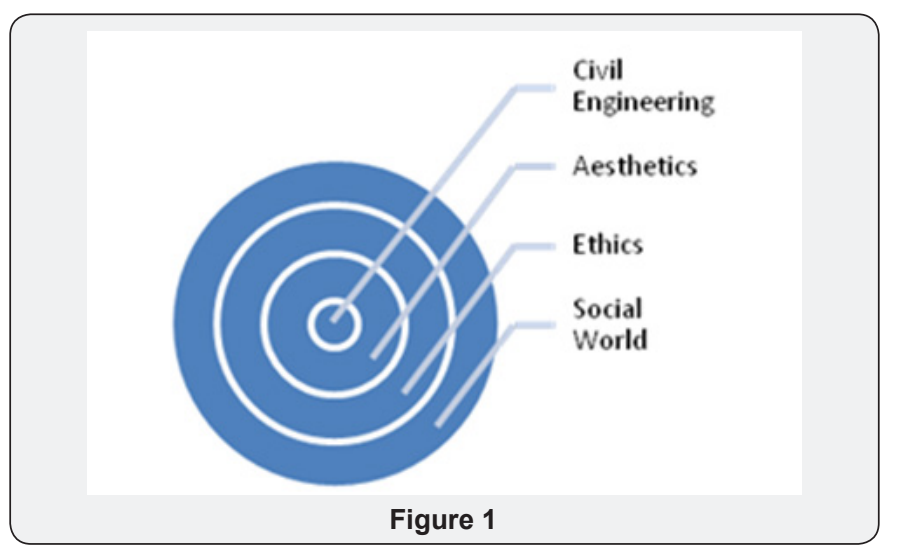


The great message from this point of view is to engineering design is that we should not exploit anything only for the results. We should have good intentions in our creativity without having the will to use nature as means only or to exploit the society for maximum profits. We should be rational in our engineering creativity that whatever we create should offer ethical space to the society. Crafting a good ethical design from the above ethical point of views we can reasonably say that the civil engineering creativity should be virtuous and serving to the social utility and be dutiful to the professional responsibilities.

\section{Concluding Remark: Engineering Creativity, Happy Society and Global Safety}

Canvassing the several explorative reasons from Aesthetics, Ethics and Socio-matrix, I have made an effort to write this guiding article in the time when actually it is very much needed for engineering creativity in general and for the civil engineering creativity in particular. The message is very clear that the engineering imagination and creativity in the civil engineering should accommodate the triple bottom line and it should be holistic in its creation like the ancient civil engineering structures and designs. The world of engineering of this time is facing several challenges because it does not encompass the concerns of ethics, environment and society [11].

The duty of the civil engineering domain is very high because it's leading engineering from the very ancient time in making humanity more equipped and civilized through creating the required engineering structures and designs. The research, technology and any such valuable effort in the civil engineering direction should take it as a policy matter that without involving ethics, aesthetics and integrity to the engineering profession a good engineering creativity structure or design cannot qualify the benchmark of the real engineering creativity. Civil Engineering represent the social character and it structures and designs represents the skill, strength and engineering will of the society [12].

This work is licensed under Creative Commons Attribution 4.0 License DOI: 10.19080/CERJ.2018.05.555651
Therefore, the entanglement of ethics, aesthetics and social-matrix should be structured in a manner shaping the civil engineering as an exemplary engineering creativity. The creativity that reflects aesthetic taste, ethical judgment and Eudemonia of such that society enjoys the creation with all happiness considering the global safety it should be harmless and holistic to the nature. And, in this way coming age and technologies should make a paradigm shift in civil engineering from mere engineering creativity to Green Virtuous Engineering Creativity. The coming research imagination should incorporate these ethical, aesthetical, and social reasons to form the future civil engineering designs and structures

\section{References}

1. Ontiveros Alexander (2013) The Great Pyramid.

2. Savitz AW (2013) The Triple Bottom Line, John Wiley \& Sons Inc, New York.

3. Baura Gail (2006) Engineering Ethics, Elsevier, Academic Press.

4. Boylan M (2017) Deontology. In: Teaching Ethics with Three Philosophical Novels. Springer, Cham.

5. Hamilton P Richard (2016) My Role and Its Virtues, The Journal of Value Enquiry 50(4): 683-685.

6. Hanson TF (1987) Engineering Creativity, TF Hanson.

7. Hendry JR, Vesilind, P.A. Clean Techn Environ Policy (2005) 7: 252.

8. Vitterso J (2016) Handbook of Eudemonic Well Being, Springer.

9. Pati JJ (2008) Harappan Architecture and Civil Engineering, Rupa and Infinity Foundation Series.

10. Smith CB (1999) Program Management BC Civil Engineering (08857024) 69(6): 34. Retrieved from EBSCO host.

11. Stafford W (1998) Utilitarianism and Liberty. In: John Stuart Mill. British History in Perspective. Palgrave, London.

12. Yuan Yuan (2016) The impact of anthropogenic activities on marine environment in Jiaozhou Bay, Qingdao, China: A review and a case study, Retrieved from Research Gate.

\section{Your next submission with Juniper Publishers} will reach you the below assets

- Quality Editorial service

- Swift Peer Review

- Reprints availability

- E-prints Service

- Manuscript Podcast for convenient understanding

- Global attainment for your research

- Manuscript accessibility in different formats

( Pdf, E-pub, Full Text, Audio)

- Unceasing customer service

Track the below URL for one-step submission https://juniperpublishers.com/online-submission.php 